ISSN 1678-3921

Journal homepage: www.embrapa.br/pab

For manuscript submission and journal contents, access: www.scielo.br/pab

\section{Roscovitine use for the delay of meiotic progression in prepubertal sheep oocytes}

\begin{abstract}
The objective of this work was to evaluate the efficiency of roscovitine on reversibly inhibiting oocytes from prepubertal sheep at the germinal vesicle (GV) stage, and to investigate the kinetics of meiosis progression after inhibitor removal. Cumulus-oocyte complexes, recovered from Sarda breed lambs aged 30-40 days, were cultured for 6 hours in a maturation medium (control) containing $75 \mu \mathrm{mol} \mathrm{L}^{-1}$ roscovitine (Rosco) at $38.5^{\circ} \mathrm{C}$ and $5 \% \mathrm{CO}_{2}$. Then, the complexes were subjected to in vitro maturation (IVM) for 18 or 23 hours, in an inhibitor-free medium supplemented with gonadotropins. The evaluation of nuclear configuration by Hoescht staining, under a fluorescence-inverted microscope, showed that $88.7 \%$ of the lamb oocytes treated with roscovitine remained at the GV stage, as observed for the immature ones (97.3\%) stained after collection. The inhibitory action was reversible; however, the proportion of oocytes $(83.3 \%)$ at the metaphase-II stage, after 23 hours of IVM, was significantly higher than that observed after 18 hours (29.5\%), in which meiosis was still in progression with $34.2 \%$ oocytes at metaphase-I, $11.6 \%$ oocytes at anaphase-I, and 18.5\% oocytes at telophase-I. Roscovitine is efficient to arrest the nuclear maturation in oocytes from prepubertal sheep; however, despite the reversibility, meiosis progression is delayed, requiring more time to be completed.
\end{abstract}

Index terms: Ovis aries, cumulus-oocyte complex, inhibitor, lamb, meiosis, nuclear maturation.

\section{Roscovitina para o atraso da progressão meiótica em oócitos de ovelhas pré-púberes}

Resumo - O objetivo deste trabalho foi avaliar a eficiência da roscovitina na inibição reversível de oócitos de ovelhas pré-púberes, no estádio de vesícula germinativa (VG), e investigar a cinética da progressão da meiose após a remoção do inibidor. Complexos cumulus-oócito, recuperados de cordeiras da raça Sarda com 30-40 dias, foram cultivados por 6 horas em meio de maturação (controle) contendo $75 \mu \mathrm{mol} \mathrm{L}{ }^{-1}$ de roscovitina (Rosco) a $38,5^{\circ} \mathrm{C}$ e $5 \%$ de $\mathrm{CO}_{2}$. Em seguida, os complexos foram submetidos à maturação in vitro (MIV) por 18 ou 23 horas, em meio isento de inibidor, suplementado com gonadotrofinas. A avaliação da configuração nuclear em coloração Hoescht, sob microscópio invertido de fluorescência, revelou que 88,7\% dos oócitos tratados permaneceram no estágio VG, conforme observado para os imaturos $(97,3 \%)$ corados após a coleta. Essa inibição foi reversível; contudo, a proporção de oócitos $(83,3 \%)$ em metáfase-II, após 23 horas de MIV, foi significativamente maior do que a observada após 18 horas (29,5\%), em que a meiose ainda estava em progressão com $34,2 \%$ de oócitos em metáfase-I, 11,6\% de oócitos em anáfase-I e 18,5\% de oócitos em telófase-I. A roscovitina é eficiente no bloqueio da maturação nuclear em oócitos de 
ovelhas pré-púberes; no entanto, apesar da reversibilidade, a progressão da meiose é retardada e requer mais tempo para ser concluída.

Termos para indexação: Ovis aries, complexo cumulusoócito, inibidor, cordeira, meiose, maturação nuclear.

\section{Introduction}

In vitro embryo production (IVP) from oocytes of prepubertal female sheep (Ovis aries) is a promising tool for the agribusiness, since it allows of reproductive life anticipation of the oocyte donor, shortening the generation interval, increasing genetic gains, and providing higher economic returns (Paramio \& Izquierdo, 2016). However, the in vitro developmental competence of prepubertal oocytes in sheep is still lower than that of adult ones (Reader et al., 2014). This fact can be attributed to ultrastructural and functional deficiencies related to incomplete cytoplasmic maturation (Salamone et al., 2001; Jimenez-Macedo et al., 2006), such as a reduced synthetic activity (Ledda et al., 2001), lower-mRNAs storage (Leoni et al., 2007), microtubules disorganization (Velilla et al., 2005), and altered organelles distribution (Velilla et al., 2006). As a result, low rates of blastocyst and high incidence of parthenogenetic activation are found. Besides, polyspermy has been registered when oocytes from prepubertal females are cultured in vitro (Reader et al., 2014).

Among the multiple steps of in vitro production (IVP), the in vitro maturation (IVM) is the most critical one, since oocytes from distinct follicles require specific conditions to complete the nuclear and cytoplasmic events necessary for the competence acquisition (Paramio \& Izquierdo, 2016). Evidences indicated that the cyclic guanosine monophosphate (cGMP), produced by granulosa cells, maintain high levels of cyclic adenosine monophosphate in the oocyte, preventing the activation of the maturation-promoting factor (MPF). Consequently, oocytes remain blocked at the germinal vesicle (GV) (Jaffe \& Egbert, 2017).

In vivo, preovulatory luteinizing hormone (LH) surge promotes a reduction of the cGMP concentration in the granulosa cells and, later, in the oocyte, due to cumulus expansion and rupture of gap junctions, resulting in meiosis resumption (Egbert et al., 2014). In vitro, in contrast, the simple removal of oocytes from the follicular environment induces the spontaneous resumption of nuclear maturation irrespectively of cytoplasmic status (Pincus \& Enzmann, 1935). In prepubertal oocytes, this interruption of the progressive competence acquisition is even more damaging than in those from adult females (Leoni et al., 2015).

In this context, the temporary maintenance of meiotic arrest has been proposed to provide an adequate time for the oocyte to complete its in vitro capacitation (Bilodeau-Goeseels, 2012). Among the studied pharmacological agents, there is an increasing interest in roscovitine, an inhibitor of cyclin-dependent kinase due to its specific action on the MPF, an important cell cycle regulator (Meijer et al., 1997). Also, it does not compromise the oocyte and embryonic development potential (Mermillod et al., 2000; Marchal et al., 2001; Han et al., 2006; Crocomo et al., 2016).

Roscovitine action has been extensively studied in oocytes from sexually mature females of several species such as swine (Ju et al., 2003), bovine (Mermillod et al., 2000; Beker-van Woundenberg et al., 2006), goat (Han et al., 2006), and sheep (Crocomo et al., 2015b, 2015c, 2015d, , 2016). Its effects on prepubertal oocytes were also reported for calves (Donnay et al., 2004; Albarracínn, et al., 2005), goats (Jimenez-Macedo et al., 2006), and gilts (Marchal et al., 2001; Romar \& Funahashi, 2006). However, no similar study on prepubertal sheep oocyte has been found in the literature, and data concerning the inhibitor usage in this species are still limited and contradictory.

The objective of this work was to evaluate the efficiency of roscovitine in reversibly inhibiting oocytes from prepubertal sheep at germinal vesicle stage, and to investigate the kinetics of meiosis progression after inhibitor removal.

\section{Materials and Methods}

This study was carried out at the University of Sassari, in the municipality of Sassari, Italy, for a period of six months. All chemicals were purchased from Sigma-Aldrich Corp. (St. Louis, MO, USA) unless otherwise indicated. The experimental procedures were approved by the Ethics Committee on the Use of Animals of the Escola de Medicina Veterinária e Ciência Animal da Universidade Estadual Paulista, in the municipality of Botucatu, in the state of São Paulo, and Universidade Federal de Minas Gerais (CEUA/ 
FMVZ n. 185/2011 and CEUA/UFMG n.13/2016), in the state of Minas Gerais, Brazil.

The experimental design was completely randomized, with two experiments and five replicates per treatment. Experiment 1 was composed of three treatments: Immature, Rosco (roscovitine), and Control. It aimed at the evaluation of the efficiency of roscovitine to inhibit the meiosis in prepubertal sheep oocytes. Experiment 2 was composed of five treatments: Control-18h, Rosco-18h, Control-23h, Rosco-23h, and Standard, and aimed to evaluate meiosis progression after inhibitor removal (Figure 1).

Ovaries of prepubertal sheep (Sarda breed lambs of 30-40 days of age) were collected at local slaughterhouses and transported to the laboratory within 1 hour, in sterile Dulbecco phosphate buffered saline (PBS) with antibiotics at $37^{\circ} \mathrm{C}$. Cumulus-oocyte complexes (COCs) were collected by slicing method, in sterile Petri dishes containing a dissection medium composed of $20 \mathrm{mmol} \mathrm{L}^{-1}$ HEPES-buffered TCM 199 supplemented with $0.1 \%$ (w/v) polyvinyl alcohol (PVA), $100 \mu \mathrm{g} \mathrm{mL} \mathrm{m}^{-1}$ penicillin, and $100 \mu \mathrm{g} \mathrm{mL}-1$ streptomycin. Only COCs with compact cumulus cell layers and homogenous cytoplasm were selected under stereomicroscopy.

After washes in HEPES-buffered TCM 199, selected COCs were cultured for 6 hours in TCM 199 maturation medium containing $0.36 \mathrm{mmol} \mathrm{L}^{-1}$ pyruvate, $100 \mu \mathrm{mol} \mathrm{L}^{-1}$ cysteamine, $100 \mu \mathrm{g} \mathrm{mL} \mathrm{m}^{-1}$ penicillin, 100 $\mu \mathrm{g} \mathrm{mL} \mathrm{m}^{-1}$ streptomycin, and $10 \%$ heat-treated oestrus sheep serum (Control); COCs belonging to the treated group (Rosco) were added with $75 \mu \mathrm{mol} \mathrm{L} \mathrm{L}^{-1}$ roscovitine. For the inhibitory effect removal, after the first six hours of culture without mineral oil coverage, COCs from each treatment were washed several times in HEPES-buffered TCM199 supplemented with 0.1\% (w/v) polyvinyl alcohol (PVA) and antibiotics (100 $\mu \mathrm{g}$ $\mathrm{mL}-1$ penicillin and streptomycin), and matured in vitro for a further 18 hours or 23 hours in the maturation medium described above, supplemented with 0.1 IU mL $\mathrm{mLSH}^{-1}$ and $0.1 \mathrm{IU} \mathrm{mL}^{-1} \mathrm{LH}$ (Pergonal, Serono, Italy), and layered with mineral oil. An additional sample of oocytes (Immature) was stained immediately after removal from the follicular environment (0 hour), and another sample (Standard) was cultured in a gonadotropin-enriched maturation medium,

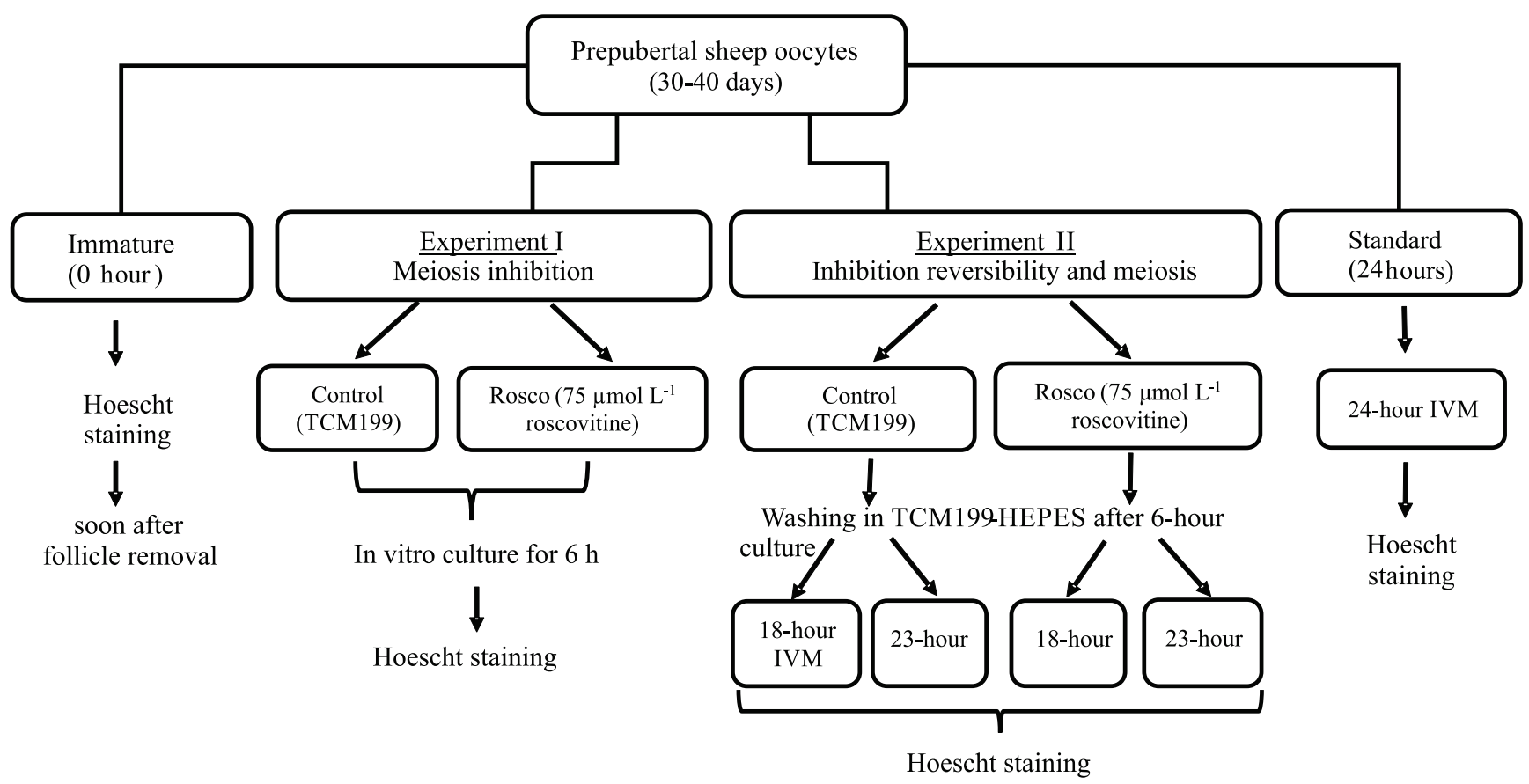

Figure 1. Schematic representation of the experimental design. TCM 199, maturation medium containing $0.36 \mathrm{mmol} \mathrm{L}^{-1}$ pyruvate, $100 \mu \mathrm{mol} \mathrm{L}^{-1}$ cysteamine, $100 \mu \mathrm{g} \mathrm{mL}^{-1}$ penicillin, $100 \mu \mathrm{g} \mathrm{mL}^{-1}$ streptomycin, and $10 \%$ heat-treated oestrus sheep serum; IVM, in vitro maturation in TCM199, supplemented with gonadotropins (luteinizing hormone and stimulating follicle). 
under mineral oil, for 24 hours without interruption (Figure 1).

In each replicate, about 20-25 COCs were randomly allocated to each $650 \mu \mathrm{L}$ droplet of the medium, in four-well Petri dishes (Nunclon, Roskilde, Denmark), and cultured in an incubator at $38.5^{\circ} \mathrm{C}$ and $5 \% \mathrm{CO}_{2}$ in air. The inhibitor concentration, inhibition time, and culture conditions were established according to Crocomo et al. (2015a, 2015b, 2015c, 2015d). The stock solution of roscovitine $\left(1 \mathrm{mg} \mathrm{mL}^{-1}\right)$ was prepared in dimethylsulphoxide, aliquoted, and stored at $-20^{\circ} \mathrm{C}$ until use.

COCs were stripped of the cumulus cells by repeated pipetting in HEPES-buffered TCM 199, fixed for $30 \mathrm{~min}$ in $4 \%$ paraformaldehyde, and transferred to $10 \mu \mathrm{L}$ droplets of Hoechst 33342 in glycerol (10 $\mu \mathrm{g} \mathrm{mL}^{-1}$ ) on a glass slide covered with a coverslip. According to the chromatin configuration observed under a fluorescence-inverted microscope (Olympus IX 70, Olympus, Tokyo, Japan), oocytes were classified as germinal vesicle $(\mathrm{GV})$, germinal vesicle breakdown (GVBD), metaphase-I (MI), anaphase-I (AI), telophase-I (TI), and metaphase-II (MII). Those with altered nuclear structure were considered degenerated (DEG) (Le Beux et al., 2003; Crocomo et al., 2015a).

Data of oocyte nuclear status (inhibition and reversibility) were subjected to the analysis of variance, and the means were compared by the Duncan's test, at $5 \%$ probability, using the R-Studio software.

\section{Results and Discussion}

Roscovitine at $75 \mu \mathrm{mol} \mathrm{L} \mathrm{L}^{-1}$ was efficient to keep lamb oocytes at GV stage $(88.7 \%)$ for 6 hours in a similar proportion to the those of the Immature treatment $(97.3 \%)$, which were stained as soon as they were collected (Table 1). The low rate of degeneration and the significant proportion of oocytes from the
Control at GVBD (33.7\%) and MI (14.4\%) indicate that culture conditions did not interfere with the meiotic progression. The result accords with those verified for oocytes from adult sheep (93.8\%) subjected to the same treatment (Crocomo et al., 2016). Studies on oocytes from sexually mature females of other species have also reported a similar meiotic inhibition efficiency, as those following described: for goats, with $78 \%$ and $85 \%$ of oocytes kept at GV stage after 24 -hour culture in $200 \mu \mathrm{mol} \mathrm{L}^{-1}$ and $250 \mu \mathrm{mol} \mathrm{L}^{-1}$ roscovitine, respectively (Han et al., 2006); for cows, with about $90 \%$ of oocytes at $\mathrm{GV}$ after 24 -hour culture in 25 $\mu \mathrm{mol} \mathrm{L}{ }^{-1}$ roscovitine (Mermillod et al., 2000; Bekervan Woundenberg et al., 2006); and, for sows, with $83 \pm 8.7 \%$ of GV after 44 -hour culture in $80 \mu \mathrm{mol} \mathrm{L}^{-1}$ roscovitine (Ju et al., 2003).

In prepubertal animals, in contrast, the results are still discrepant. While, in gilts, more than $90 \%$ oocytes were at GV, after culture for 22 hours in $25 \mu \mathrm{mol} \mathrm{L}-1$ roscovitine (Marchal et al., 2001), and 48 hours in 50 $\mu \mathrm{mol} \mathrm{L}{ }^{-1}$ roscovitine (Romar \& Funahashi, 2006), a low proportion of oocytes from prepubertal goats remained arrested at this stage $(<30 \%)$ for 24 hours at different roscovitine concentrations $(12.5,25,50$, and 100 $\mu \mathrm{mol} \mathrm{L}-1$ ) (Jimenez-Macedo et al., 2006). According to Jimenez-Macedo et al. (2006), the low-blocking efficiency is explained by the fact that a high rate of oocytes $(73.8 \%)$ resumes the meiosis before roscovitine exposition. Roscovitine inhibits the activation of the M-phase promoting factor (MPF) which, once active, phosphorylates some target proteins, as mitogenactivated protein kinases (MPAK), involved in the resumption and progression of meiosis (Meijer et al., 1997; Vigneron et al., 2004). In the present study, it was confirmed that most immature oocytes were at GV stage (97.3\%) to ensure the maximum inhibitory potential.

Table 1. Nuclear configuration of prepubertal sheep (Sarda breed) oocytes at 0 hour (Immature) and after 6 hours of in vitro culture, in the absence (Control) or presence of $75 \mu \mathrm{mol} \mathrm{L}-1$ roscovitine (Rosco) $)^{(1)}$.

\begin{tabular}{|c|c|c|c|c|c|c|c|c|}
\hline \multirow{2}{*}{ Treatment } & \multirow{2}{*}{$\begin{array}{l}\text { Oocyte } \\
\text { (n) }\end{array}$} & \multicolumn{7}{|c|}{ Nuclear configuration, $\mathrm{n}(\%)$} \\
\hline & & $\mathrm{GV}$ & GVBD & MI & $\mathrm{AI}$ & TI & MII & DEG \\
\hline Control & 104 & $50(48.1) \mathrm{bA}$ & $35(33.7) \mathrm{aB}$ & $15(14.4) \mathrm{aC}$ & $0(0.0) \mathrm{aD}$ & $0(0.0) \mathrm{aD}$ & $2(1.9) \mathrm{aD}$ & $2(1.9) \mathrm{aD}$ \\
\hline Rosco & 97 & $86(88.7) \mathrm{aA}$ & 7 (7.2) bB & $1(1.0) \mathrm{bB}$ & $0(0.0) \mathrm{aB}$ & $0(0.0) \mathrm{aB}$ & $1(1.0) \mathrm{aB}$ & $2(2.1) \mathrm{aB}$ \\
\hline Immature & 113 & $110(97.3) \mathrm{aA}$ & $3(2.7) \mathrm{bB}$ & $0(0.0) \mathrm{bB}$ & $0(0.0) \mathrm{aB}$ & $0(0.0) \mathrm{aB}$ & $0(0.0) \mathrm{aB}$ & $0(0.0) \mathrm{aB}$ \\
\hline
\end{tabular}

${ }^{(1)}$ Means followed by equal letters, uppercase in the rows and lowercase in the columns, do not differ by the Duncan test, at $5 \%$ probability. GV, germinal vesicle; GVBD; germinal vesicle breakdown; MI, metaphase I; AI, anaphase; TI, telophase; MII, metaphase II; and DEG, degenerated. 
In calves, Albarracínn et al. (2005) verified the need of a higher-roscovitine dose $\left(50 \mu \mathrm{mol} \mathrm{L}^{-1}\right)$ than the standard levels for cows $\left(25 \mu \mathrm{mol} \mathrm{L}^{-1}\right)$ (Mermillod et al., 2000; Beker-van Woundenberg et al., 2006) to prevent the meiosis resumption in, approximately, $60 \%$ of oocytes only. According to the first authors, the factors involved in the discrepancy are not clear and may be related to the IVM system, composition of maturation medium, heterogeneity of ovaries batches, and inhibitor source. In the present study, however, the efficiency of meiotic inhibition was maintained with the same roscovitine dose and culture time previously established for oocytes from sexually mature sheep (Crocomo et al., 2016).

Despite the complete reversion of roscovitine action in gonadotropin-supplemented medium, the kinetics of meiotic progression in prepubertal sheep oocytes after inhibition was delayed, in comparison to that reported for oocytes from sexually mature females. While in previous studies with adult oocytes, 18 hours of IVM were sufficient for the completion of nuclear maturation (93.6\% MII) (Crocomo et al., 2016), in the present study, the rate of oocytes from prepubertal sheep at MII stage (83.3\%), after 23 hours of IVM, was significantly higher than that observed after IVM for 18 hours $(29.5 \%)$ and similar to the Standard (89.3\%), prevailing over the other meiotic stages (Table 2). The significant proportion of oocytes at metaphase-I (34.2\%), anaphase-I (11.6\%), and telophase-I (18.5\%), at the end of culture for 18 hours in inhibitor-free medium supplemented with gonadotropins, after roscovitine treatment, also reinforces that meiosis was still in progress.

The MII rate observed after 23-hour IVM was higher than those registered for oocytes from calves after 17 hours or 24 hours of IVM (60\% MII) (Donnay et al., 2004), and from prepubertal goats after 24-hour IVM (50-60\% MII) (Jimenez-Macedo et al., 2006). However, MII rate after 23-hour IVM was similar to those reported for prepubertal gilts $(92.1 \pm 2.9 \%)$ (Romar \& Funahashi, 2006), sexually mature cows ( $89 \pm 4 \%$ MII) (Mermillod et al., 2000), and cyclic goats (80\% MII) (Han et al., 2006). Therefore, the conditions of inhibition and maturation used in the present study did not compromise the oocyte competence in relation to nuclear events. However, it is important to highlight that the differences observed among authors on the action efficiency of roscovitine and its reversibility depend on the culture conditions used, such as inhibitor dose, time of exposition and maturation, and species characteristics (Mermillod et al., 2000; Ju et al., 2003; Han et al., 2006).

The meiosis progression tends to be accelerated after the inhibitory treatment with roscovitine, due to the accumulation of some factors that act upstream MPF activation, since this inhibitor prevents the activities of cyclin-dependent kinases, but not those of the synthesis and phosphorylation of other proteins involved in the oocyte maturation process (Vigneron et al., 2004). For oocytes from sexually mature goats (Han et al., 2006) and prepubertal gilts (Marchal et al., 2001), it was still verified that the longer is the inhibition period, the more pronounced is the meiosis acceleration. However, for bovine prepubertal oocytes, this assumption has not been confirmed (Donnay et al., 2004). For lamb oocytes, however, our results indicate that kinetics of nuclear maturation is delayed after meiotic inhibition, which is probably due to the ultrastructural and functional deficiencies already reported for prepubertal oocytes (Salamone et al.,

Table 2. Meiotic progression of prepubertal sheep (Sarda breed) oocytes cultured in vitro for 6 hours, either in the absence (Control) or the presence of $75 \mu \mathrm{mol} \mathrm{L} \mathrm{L}^{-1}$ roscovitine (Rosco), followed by in vitro maturation for 18 hours or 23 hours in gonadotropin-enriched medium $\left(0.1 \mathrm{IU} \mathrm{mL}^{-1}\right.$ follicle-stimulating hormone_and $0.1 \mathrm{IU} \mathrm{mL}^{-1}$ luteinizing hormone. In vitro maturation (IVM) was performed for 24 hours, without interruption, in gonadotropin-enriched medium (Standard) ${ }^{(1)}$.

\begin{tabular}{|c|c|c|c|c|c|c|c|c|c|}
\hline \multirow[t]{2}{*}{ Treatment } & \multirow{2}{*}{$\begin{array}{l}\text { IVM time } \\
\text { (h) }\end{array}$} & \multirow{2}{*}{$\begin{array}{l}\text { Oocyte } \\
\text { (n) }\end{array}$} & \multicolumn{7}{|c|}{ Nuclear maturation stage, $\mathrm{n}(\%)$} \\
\hline & & & GV & GVBD & MI & $\mathrm{AI}$ & TI & MII & DEG \\
\hline Standard & 24 & 103 & $0(0.0) \mathrm{aB}$ & $0(0.0) \mathrm{aB}$ & $9(8.7) \mathrm{bB}$ & $0(0.0) \mathrm{aB}$ & $0(0.0) \mathrm{bB}$ & $92(89.3) \mathrm{aA}$ & $2(1.9) \mathrm{aB}$ \\
\hline \multirow{2}{*}{ Control } & 18 & 123 & $10(8.1) \mathrm{aC}$ & $2(1.6) \mathrm{aC}$ & $30(24.4) \mathrm{aB}$ & $3(2.4) \mathrm{aC}$ & $3(2.4) b C$ & $70(56.9) \mathrm{cA}$ & $5(4.1) \mathrm{aC}$ \\
\hline & 23 & 143 & $5(3.5) \mathrm{aC}$ & $0(0.0) \mathrm{aC}$ & $22(15.4) \mathrm{bB}$ & $1(0.7) \mathrm{aC}$ & $0(0.0) \mathrm{bC}$ & $102(71.3) \mathrm{bA}$ & $13(9.1) \mathrm{aBC}$ \\
\hline \multirow{2}{*}{ Rosco } & 18 & 146 & $6(4.1) \mathrm{aC}$ & $2(1.4) \mathrm{aC}$ & $50(34.2) \mathrm{aA}$ & $17(11.6) \mathrm{aBC}$ & $27(18.5) \mathrm{aB}$ & $43(29.5) \mathrm{dA}$ & $1(0.7) \mathrm{aC}$ \\
\hline & 23 & 50 & $3(2.0) \mathrm{aB}$ & $3(2.0) \mathrm{aB}$ & $12(8.0) \mathrm{bB}$ & $2(1.3) \mathrm{aB}$ & $1(0.7) \mathrm{bB}$ & $125(83.3) \mathrm{aA}$ & $4(2.7) \mathrm{aB}$ \\
\hline
\end{tabular}

(1) Means followed by equal letters, uppercase in the rows and lowercase in the columns, do not differ by the Duncan test, at $5 \%$ probability. GV, germinal vesicle; GVBD, germinal vesicle breakdown; MI, metaphase I; AI, anaphase; TI, telophase; MII, metaphase II; DEG, degenerated. 
2001; Leoni et al., 2015). Therefore, they require more time for the completion of in vitro maturation.

In accordance, Palmerini et al. (2014) have reported a delay in the progression of events related not only to meiosis, but also to cytoplasmic maturation, which, as reported by these authors, explains the reduced developmental competence of prepubertal sheep oocytes. Leoni et al. (2015) have also shown that the MII rate at 19 hours of IVM in oocytes from cyclic sheep is comparable to that observed at 21 hours of IVM in lamb oocytes, and this difference is amplified during the embryo development. Therefore, it is important to wait the time required for maturation completion without, however, overextending IVM, since it may induce the aging of the oocyte and reduce its capacity to be fertilized, or support embryonic development (Koyama et al., 2014)

The meiosis progression in oocytes from the Control showed a similar pattern to that from the roscovitine treatment, since the MII proportion after 18-hour IVM (56.9\%) was significantly lower than that observed at 23-hour IVM (71.3\%) (Table 2). Besides, for both conditions (Control-18h and 23h), the MII rate was significantly lower than that of the Standard treatment (89.3\%), in which the IVM was performed for 24 hours, without interruption, in a gonadotropin-enriched medium. It indicates that the lack of gonadotropins, as well as the culture interruption and manipulation of oocytes, in the absence of roscovitine, interferes with the meiotic kinetics. Despite that, the low proportion of degenerated oocytes in all treatments reinforces that the experimental conditions established in the present study were adequate for oocyte nuclear competence acquisition.

\section{Conclusion}

Roscovitine is efficient to arrest the nuclear maturation in oocytes from prepubertal Sarda breed sheep (Ovis aries); however, despite the reversibility of its action, the meiosis progression requires more time to be completed after the inhibitory treatment with roscovitine.

\section{Acknowledgments}

To Fundação de Amparo à Pesquisa do Estado de São Paulo (Fapesp; 2013/05564-0, 2011/14041-5, 2011/18843-9), for scholarship and financial support; and to Pró-Reitoria de Pesquisa of Universidade Federal de Minas Gerais (05/2016).

\section{References}

ALBARRACÍNN, J.L.; MORATÓ, R.; IZQUIERDO, D.; MOGAS, T. Effects of roscovitine on the nuclear and cytoskeletal components of calf oocytes and their subsequent development. Theriogenology, v.64, p.1740-1755, 2005. DOI: https://doi.org/10.1016/j.theriogenology.2005.04.018.

BEKER-VAN WOUDENBERG, A.R.; ZEINSTRA, E.C.; ROELEN, B.A.J.; COLENBRANDER, B.; BEVERS, M.M. Developmental competence of bovine oocytes after specific inhibition of MPF kinase activity: effect of estradiol supplementation and follicle size. Animal Reproduction Science, v.92, p.231-240, 2006. DOI: https://doi.org/10.1016/j. anireprosci.2005.05.026.

BILODEAU-GOESEELS, S. Bovine oocyte meiotic inhibition before in vitro maturation and its value to in vitro embryo production: does it improve developmental competence? Reproduction in Domestic Animals, v.47, p.687-693, 2012. DOI: https://doi.org/10.1111/j.1439-0531.2011.01924.x.

CROCOMO, L.F.; ARIU, F.; BOGLIOLO, L.; BEBBERE, D.; LEDDA, S.; BICUDO, S.D. In vitro developmental competence of adult sheep oocytes treated with roscovitine. Reproduction in Domestic Animals, v.51, p.276-281, 2016. DOI: https://doi.org/10.1111/rda.12677.

CROCOMO, L.F.; MARQUES FILHO, W.C.; ACKERMANN, C.L.; LIMA, P.F. de; BURATINI JUNIOR, J.; LANDIMALVARENGA, F. da C.; BICUDO, S.D. Gene expression in sheep cumulus-oocyte complexes meiotically inhibited with roscovitine. Small Ruminant Research, v.132, p.115-122, 2015a. DOI: https://doi.org/10.1016/j.smallrumres.2015.10.014.

CROCOMO, L.F.; MARQUES FILHO, W.C.; ACKERMANN, C.L.; PASCHOAL, D.M.; GUASTALI, M.D.; MAZIERO, R.R.D.; SUDANO, M.J.; LANDIM-ALVARENGA, F. da C.; BICUDO, S.D. Time course of the meiotic arrest in sheep cumulus-oocyte complexes treated with roscovitine. Zygote, v.24, p.310-318, 2015b. DOI: https://doi.org/10.1017/S0967199415000234.

CROCOMO, L.F.; MARQUES FILHO, W.C.; ULIAN, C.M.V.; BRANCHINI, N.S.; SILVA, D.T.; ACKERMANN, C.L.; LANDIM-ALVARENGA, F.C.; BICUDO, S.D. Effect of oil overlay on inhibition potential of roscovitine in sheep cumulusoocyte complexes. Reproduction in Domestic Animals, v.50, p.410-416, 2015c. DOI: https://doi.org/10.1111/rda.12506.

CROCOMO, L.F.; ULIAN, C.M.V.; BRANCHINI, N. da S.; SILVA, D.T. da; MARQUES FILHO, W.C.; ALVARENGA, F. da C.L.; BICUDO, S.D. Meiotic arrest of sheep oocytes using roscovitine under different medium compositions. Small Ruminant Research, v.126, p.52-58, 2015d. DOI: https://doi.org/10.1016/j.smallrumres.2015.02.022.

DONNAY, I.; FAERGE, I.; GRONDAHL, C.; VERHAEGE, B.; SAYOUD, H.; PONDERATO, N.; GALLI, C.; LAZZARI, G. Effect of prematuration, meiosis activating sterol and enriched maturation medium on the nuclear maturation and competence to 
development of calf oocytes. Theriogenology, v.62, p.1093-1107, 2004. DOI: https://doi.org/10.1016/j.theriogenology.2003.12.019.

EGBERT, J.R.; SHUHAIBAR, L.C.; EDMUND, A.B.; VAN HELDEN, D.A.; ROBINSON, J.W.; ULIASZ, T.F.; BAENA, V.; GEERTS, A.; WUNDER, F.; POTTER, L.R.; JAFFE, L.A. Dephosphorylation and inactivation of NPR2 guanylyl cyclase in granulosa cells contributes to the LH-induced decrease in cGMP that causes resumption of meiosis in rat oocytes. Development, v.141, p.3594-3604, 2014. DOI: https://doi.org/10.1242/dev.112219.

HAN, D.; LAN, G.-C.; WU, Y.-G.; HAN, Z.-B.; WANG, H.-L.; TAN, J.-H. Factors affecting the efficiency and reversibility of roscovitine (ros) block on the meiotic resumption of goat oocytes. Molecular Reproduction and Development, v.73, p.238-246, 2006. DOI: https://doi.org/10.1002/mrd.20398.

JAFFE. L.A.; EGBERT, J.R. Regulation of mammalian oocyte meiosis by intercellular communication within the ovarian follicle. Annual Review of Physiology, v.79, p.237-260, 2017. DOI: https://doi.org/10.1146/annurev-physiol-022516-034102.

JIMENEZ-MACEDO, A.R.; IZQUIERDO, D.; URDANETA, A.; ANGUITA, B.; PARAMIO, M.T. Effect of roscovitine on nuclear maturation, MPF and MAP kinase activity and embryo development of prepubertal goat oocytes. Theriogenology, v.65, p.1769-1782, 2006. DOI: https://doi.org/10.1016/j.theriogenology.2005.10.012.

JU, J.-C.; TSAY, C.; RUAN, C.-W. Alterations and reversibility in the chromatin, cytoskeleton and development of pig oocytes treated with roscovitine. Molecular Reproduction and Development, v.64, p.482-491, 2003. DOI: https://doi.org/10.1002/mrd.10234.

KOYAMA, K.; KANG, S.-S.; HUANG, W.; YANAGAWA, Y.; TAKAHASHI, Y.; NAGANO, M. Aging-related changes in in vitro-matured bovine oocytes: Oxidative stress, mitochondrial activity and ATP content after nuclear maturation. Journal of Reproduction and Development, v.60, p.136-142, 2014. DOI: https://doi.org/10.1262/jrd.2013-115.

LE BEUX, G.; RICHARD, F.J.; SIRARD, M.-A. Effect of cycloheximide, 6-DMAP, roscovitine and butyrolactone I on resumption of meiosis in porcine oocytes. Theriogenology, v.60, p.1049-1058, 2003. DOI: https://doi.org/10.1016/S0093691X(03)00124-9.

LEDDA, S.; BOGLIOLO, L.; LEONI, G.; NAITANA, S. Cell coupling and maturation-promoting factor activity in in vitro-matured prepubertal and adult sheep oocytes. Biology of Reproduction, v.65, p.247-252, 2001. DOI: https://doi.org/10.1095/biolreprod65.1.247.

LEONI, G.G.; BEBBERE, D.; SUCCU, S.; BERLINGUER, F.; MOSSA, F.; GALIOTO, M.; BOGLIOLO, L.; LEDDA, S.; NAITANA. S. Relations between relative mRNA abundance and developmental competence of ovine oocytes. Molecular Reproduction and Development, v.74, p.249-257, 2007. DOI: https://doi.org/10.1002/mrd.20442.

LEONI, G.G.; PALMERINI, M.G.; SATTA, V.; SUCCU, S.; PASCIU, V.; ZINELLU, A.; CARRU, C.; MACCHIARELLI, G.; NOTTOLA, S.A.; NAITANA, S.; BERLINGUER. F. Differences in the kinetic of the first meiotic division and in active mitochondrial distribution between prepubertal and adult oocytes mirror differences in their developmental competence in a sheep model. Plos One, v.10, e0124911, 2015. DOI: https://doi. org/10.1371/journal.pone.0124911.

MARCHAL, R.; TOMANEK, M.; TERQUI, M.; MERMILLOD, P. Effects of cell cycle dependent kinases inhibitor on nuclear and cytoplasmic maturation of porcine oocytes. Molecular Reproduction and Development, v.60, p.65-73, 2001. DOI: https://doi.org/10.1002/mrd.1062.

MEIJER, L.; BORGNE, A.; MULNER, O.; CHONG, J.P.J.; BLOW, J.J.; INAGAKI, N.; INAGAKI, M.; DELCROS, J.G.; MOULINOUX, J.-P. Biochemical and cellular effects of roscovitine, a potent and selective inhibitor of the cyclin-dependent kinases cdc2, cdk2 and cdk5. European Journal of Biochemistry, v.243, p.527-536, 1997. DOI: https://doi.org/10.1111/j.1432-1033.1997.t01-2-00527.x.

MERMILLOD, P.; TOMANEK, M.; MARCHAL, R.; MEIJER, L. High developmental competence of cattle oocytes maintained at the germinal vesicle stage for $24 \mathrm{~h}$ in culture by specific inhibition of MPF kinase activity. Molecular Reproduction and Development, v.55, p.89-95, 2000. DOI: https://doi.org/10.1002/ (SICI)1098-2795(200001)55:1<89::AID-MRD12>3.0.CO;2-M.

PALMERINI, M.G.; NOTTOLA, S.A.; LEONI, G.G.; SUCCU, S.; BORSHI, X.; BERLINGUER, F.; NAITANA, S.; BEKMUKHAMBETOV, Y.; MACCHIARELLI, G. In vitro maturation is slowed in prepubertal lamb oocytes: ultrastructural evidences. Reproductive Biology and Endocrinology, v.12, art.115, 2014. DOI: https://doi.org/10.1186/1477-7827-12-115.

PARAMIO, M.-T.; IZQUIERDO, D. Recent advances in in vitro embryo production in small ruminants. Theriogenology, v.86, p.152-159, 2016. DOI: https://doi.org/10.1016/j. theriogenology.2016.04.027.

PINCUS, G.; ENZMANN, E.V. The comparative behaviour of mammalian eggs in-vivo and in-vitro. I. The activation of ovarian eggs. Journal of Experimental Medicine, v.62, p.665-675, 1935. DOI: https://doi.org/10.1084/jem.62.5.665.

READER, K.L.; COX, N.R.; STANTON, J.-A.L.; JUENGEL, J.L. Mitochondria and vesicles differ between adult and prepubertal sheep oocytes during IVM. Reproduction, Fertility and Development, v.27, p.513-522, 2014. DOI: https://doi.org/10.1071/ RD13359.

ROMAR, R.; FUNAHASHI, H. In vitro maturation and fertilization of porcine oocytes after a $48 \mathrm{~h}$ culture in roscovitine, an inhibitor of $\mathrm{p} 34^{\mathrm{cdc} 2} / \mathrm{cyclin} \mathrm{B}$ kinase. Animal Reproduction Science, v.92, p.321-333, 2006. DOI: https://doi.org/10.1016/j. anireprosci.2005.04.017.

SALAMONE, D.F.; DAMIANI, P.; FISSORE, R.A.; ROBL, J.M.; DUBY, R.T. Biochemical and developmental evidence that ooplasmic maturation of prepubertal bovine oocytes is compromised. Biology of Reproduction, v.64, p.1761-1768, 2001. DOI: https://doi.org/10.1095/biolreprod64.6.1761.

VELILLA, E.; RODRÍGUEZ-GONZALEZ, E.; VIDAL, F.; IZQUIERDO, D.; PARAMIO, M.-T. Mitochondrial organization in prepubertal goat oocytes during in vitro maturation and fertilization. Molecular Reproduction and Development, v.73, p.617-626, 2006. DOI: https://doi.org/10.1002/mrd.20426. 
VELILLA, E.; RODRÍGUEZ-GONZALEZ, E.; VIDAL, F.; PARAMIO, M.-T. Microtubule and microfilament organization in immature, in vitro matured and in vitro fertilized prepubertal goat oocytes. Zygote, v.13, p.155-165, 2005. DOI: https://doi.org/10.1017/S0967199405003229.
VIGNERON, C.; PERREAU, C.; DALBIÈS-TRAN, R.; JOLY, C.; HUMBLOT, P.; UZBEKOVA, S.; MERMILlOD, P. Protein synthesis and mRNA storage in cattle oocytes maintained under meiotic block by roscovitine inhibition of MPF activity. Molecular Reproduction and Development, v.69, p.457-465, 2004. DOI: https://doi.org/10.1002/mrd.20172. 